Kalem Eğitim ve İnsan Bilimleri Dergisi 2017, 7(2), doi: 10.23863/kalem.2018.93

Makale Gönderim Tarihi:05.10.2016

Makale Kabûl Tarihi:15.03.2017

\title{
12-14 Yaş Arası Ergenlerin Sosyal Beceri Düzeyi ile Ebeveynlerine Bağlanma Güvenliği Arasındaki İlişkinin İncelenmesi ${ }^{1}$
}

\author{
Arş. Gör. Asya ÇETİN* \\ Karabük Üniversitesi, Sağlık Bilimleri Fakültesi, Karabük / Türkiye, \\ cetin.asya@gmail.com, ORCID: 0000-0002-2756-5322 \\ Yrd. Doç. Dr. Özlem ALKAN-ERSOY \\ Gazi Üniversitesi, Eğitim Fakültesi, Ankara / Türkiye, \\ ozlemerso@gmail.com, ORCID: 0000-0002-4171-754
}

\section{$\ddot{\mathbf{O z}}$}

$\mathrm{Bu}$ araştırma, 12-14 yaş arası ergenlerin sosyal beceri düzeyi ile ebeveynlerine bağlanma güvenliği arasındaki ilişkiyi belirlemek amacıyla hazırlanmıştır. Araştırmanın örneklemini 2014-2015 eğitim-öğretim yılında Karabük il merkezinde Millî Eğitim Bakanlı̆̆ı'na bağlı 6 okulun 6,7 ve 8. sinıflarında öğrenim gören 12-14 yaş grubundan 186 erkek, 169 kız olmak üzere toplam 355 ergen oluşturmuştur. Nicel araştırma yöntemlerinden tarama modeli kullanılarak yapılan araştırmada veriler, "Matson Çocuklarda Sosyal Becerileri Değerlendirme Ölçeği (MESSY)" ve "Ebeveyn ve

\footnotetext{
${ }^{1}$ Bu çalışma Özlem Alkan-Ersoy danışmanlığında Asya Çetin tarafından hazırlanan "12-14 Yaş Arası Ergenlerin Sosyal Beceri Düzeyi ile Ebeveynlerine Bağlanma Güvenliği Arasındaki İlişkinin İncelenmesi” adlı yüksek lisans tezinden türetilmiştir.

* Sorumlu Yazar. Tel: +90 5443910571

(C) 2017 Kalem Eğitim ve Sağlık Hizmetleri Vakfı. Bütün Hakları Saklıdır. ISSN: 2146-5606
} 
Arkadaşlara Bağlanma Ölçeği (EABE)” ve araştırmacı tarafından hazırlanan "Kişisel Bilgi Formu" aracılığıyla toplanmıştır. Ergenlerin ebeveyn bağlanma puanları ile olumlu sosyal davranışları arasında bir ilişki olduğu tespit edilmiştir.

Anahtar Kelimeler: Bağlanma; Sosyal beceri; Ergenlik dönemi.

\title{
Investigation of the Secure Parent Attachment of Adolescents Between 12-14 Years in Terms of Some Variables
}

\begin{abstract}
The objective of the research is to determine the relationship between the scale of social skills of the adolescents at the age of 12-14 and their secure parent attachment. The sample of the research comprises of 186 male and 169 female adolescents with a total of 355 at the age of 12-14 who are studying in the $6^{\text {th }}, 7^{\text {th }}$ and $8^{\text {th }}$ grade in six schools in Karabük under the administration of the Ministry of National Education in the school year of 2014-2015. The data collection for this research which has been conducted with the quantitative research and scanning method has been carried out by means of Matson Evaluation of Social Skills with Youngsters (MESSY) and Inventory of Parent and Peer Attachment (IPPA). It has been determined that there is a relationship between parental attachment scores and positive social behavior of adolescents.
\end{abstract}

Keywords: Attachment; Social skills; Adolescence.

\section{Extended Summary}

\section{Purpose}

The purpose of the research is to determine the relationship between the scale of social skills of the adolescents at the age of 12-14 and their secure parent attachment.

\section{Method}

The sample of the research comprises of 186 male and 169 female adolescents with a total of 355 at the age of $12-14$ who are studying in the $6^{\text {th }}, 7^{\text {th }}$ and $8^{\text {th }}$ grade in six schools that have been selected with the systematical sampling method from the secondary schools depending on the total number 
of students in the province of Karabük under the administration of the Ministry of National Education in the school year of 2014-2015. The data collection for this research which has been conducted with the quantitative research and scanning method has been carried out by means of Matson Evaluation of Social Skills with Youngsters (MESSY), which has been developed by Matson, Rotatory and Hessel (1983) and adapted to Turkish by Bacanlı and Erdoğan (2003), Inventory of Parent and Peer Attachment (IPPA), which has been developed by Armsden and Greenberg (1987) and used in the Turkish sampling by Kumru (2002) and "Personal Information Form” which has been prepared by the researcher. In order to analyze whether there is statistically a significant relationship among the variables SPSS 20.00 packaged software has been used. ShapiroWilk's has been used to investigate the normally distributed variables due to their number of units. While studying the differences between the groups Mann Whitney U and Kruskal Wallis-H Tests have been used for non-normally distributed variables. Where significant differences detected in Kruskal Wallis-H Test. For the study of the relations between non-normally distributed variables Spearman's Correlation Coefficient has been used. On the other hand, Mann Whitney U and Kruskal Wallis-H Tests and Pearson correlation coefficient have been put to use so as to solve the sub problems of the research.

\section{Result}

The results of the research have determined that the sub-dimension points of MESSY "Positive Social Behaviors" of the adolescents differ significantly $(p<0.05)$ in terms of gender $(p=0.002)$, age of mother $(p=0.049)$ and father $(p=0.049)$, father's educational background $(p=0.001)$, but they don't differ significantly $(p>0.05)$ in terms of class variables $(p=0.569)$, number of siblings $(p=0.303)$, birth order $(p=0.409)$, mother's educational background $(p=0.513)$, mother's $(p=0.235)$ and father's $(p=0.378)$ occupational status, mother's $(p=0.835)$ and father's $(p=0.620)$ occupation and family size $(p=0.528)$. It has also been determined that the sub-dimension points of MESSY "Negative Social Behaviors" of the adolescents differ significantly $(p<0.05)$, in terms of class $(p=0.001)$ and gender variables $(p=0.001)$, but they don't differ significantly in $(p>0.05)$ terms of number of siblings, birth order ( $p=0.927)$, mother $(p=0.206)$ and father $(p=0.986)$ age, mother's ( $p=0.237)$ and father's ( $p=0.065)$ educational background, mother's $(p=0.144)$ and father's $(p=0.106)$ occupational status, mother $(p=0.368)$ and father ( $p=0.493$ ) occupation and family type $(p=0.769)$. In addition, it has 
been concluded that the total points of MESSY differ significantly $(p<0.05)$ in terms of mother's educational background $(p=0.001)$ and mother's occupational status ( $p=0.035)$, but they don't differ significantly $(p>0.05)$ in terms of class $(p=0.180)$, gender $(p=0.281)$, number of siblings ( $p=0.698)$, birth order $(p=0.789)$, mother $(p=0.761)$ and father $(p=0.211)$ age, mother's educational background $(p=0.341)$, father's occupational status $(p=0.797)$, mother's $(p=0.183)$ and father's $(p=0.610)$ occupation and family type $(p=0.564)$. Besides other findings it has also been found out that the points the adolescents have received from IPPA's "Parent Attachment Sub-Dimension" differ significantly $(p<0.05)$ in terms of class $(p=0.001)$, mother's $(p=0.047)$ and father's ( $p=0.001$ ) educational background, but they don't differ significantly in terms of gender $(p=0.687)$, number of siblings $(p=0.833)$, birth order $(p=0.311)$, mother $(p=0.291)$ and father $(p=0.998)$ age, mother's $(p=0.984)$ and father's ( $p=0.993)$ occupational status, mother's $(p=0.819)$ and father's ( $p=0.724)$ occupation and family type $(p=0.813)$. It has been determined that there is a positively weak relation between the adolescents' positive social behavior scores and their parental attachment scores $(r=0.245)$; that there is a negatively weak relation between the adolescents' negative social behavior scores and their parental attachment scores $(r=-0.182)$.

\section{Discussion and Conclusion}

As a result of studying the scale of social skills and secure parent attachment of the adolescents according to some variables; it was determined that as the parental attachment scores of adolescents increased, positive social behavior increased and negative social behavior decreased. In the relevant literature there are studies supporting this finding (Allen, Hauser and Borman-Spurrell, 1996; Richard, 2002).

Considering the results of the study and literature information, it can be said that healthy parental attitudes have a direct impact on the development of children and adolescents and reflected in their whole lives.

\section{Giriş}

Ergenlik dönemi; bireyin akran, toplum gibi ebeveynleri dışındaki diğer sistemlere yöneldiği ve bağımsızlık dengesinde değişikliklerin olduğu bir dönemdir (Christie ve Viner, 2005). Fiziksel, psikolojik, bilişsel ve sosyal açıdan değişimler yaşayan ergenin bu dönemde ebeveynlerine olan bağımlılığı azalır, hem ebeveynleriyle hem de akranlarıyla olan ilişkilerinde farkl1laşmalar başlar. Bu dönemde akranlar, bağlanma güvenliği açısından önemli 
hâle gelirler (Bayraktar, Sayıl ve Kumru, 2009; Eisenberg ve Morris, 2004). Arkadaşlık ilişkilerindeki farklılıklar ebeveyn-çocuk etkileşimindeki farkl1lıklardan kaynaklanır. Bağlanma kuramına göre çocuğun ebeveyniyle olan duygusal bağı, ileriki hayatında diğer yakın ilişkilerine etki eder ve güçlü bir öngörü oluşturur (Waters ve Cummings, 2000). Ebeveyne bağlanma, ergenlerin romantik ilişkilerini, ilişkilerdeki samimiyetlerini ve sağlıklı akran ilişkileri kurma gibi sosyal ilişkilerini etkiler. Güvenli bağlanma, ergenlerin kendilerini güvende hissetmelerini, aile, akran ortamlarında sosyal beceriler sergilemelerini olumlu yönde etkiler. Akran ilişkileri doğası gereği ebeveynle olan ilişkilere göre daha eşitlikçi ve simetriktir. Ergenlerin aile dişındaki ilişkilerinin temel özellikleri göz önüne alındığında sosyal beceriler ile ilgili yetkinlikler, akranlarla tatmin edici ilişkiler kurulması açısından gereklidir. Ebeveynine bağlı ergenler arkadaşlarıyla samimi, tatmin edici ilişkileri başlatma ve sürdürme konusunda yeterli sosyal becerileri geliştirirler (Engels, Finkenauer ve Meeus, 2001). Bağlanma figürünün ihtiyaçlarına cevap vereceğine, destek ve koruma sağlayacağına güvenen birey, akademik ve sosyal hayatında olumlu ilişkiler kurma ve keşfetme davranışı sergiler. Bu nedenle, ebeveynlerin ergenlerin hayatlarında önemli birer sosyalleşme aracı olduğu söylenebilir (Allen, Hauser ve Borman-Spurrell, 1996).

Ergenler farklı sosyal beklentilerle karşı karşıya kaldıklarından, yeni sosyal roller üstlenmek durumundadırlar. Bu dönemde aile ve arkadaşlarıyla olan sosyal ilişkilerini yeniden tanımlama ihtiyacı duyarlar (Kirchler, Palmonari ve Pombeni, 1993). Bu nedenle akranlarıyla olan iletişim ve etkileşimleri ile ilgili kendilerini yeniden tanımlamaya başlarken diğer bireylerin kendileriyle olan iletişim ve etkileşim şekillerini de gözden geçirirler (Christie ve Viner, 2005). Akran etkileşimi, ergenin ev ortamı dışında sosyal becerilerinin gelişimine katkı sağlar ve bağımsızlığa doğru geçişini kolaylaştırır. Bunun yanı sıra sosyal kabulü olan davranışları seçme, sosyal beceriler ile ilgili uygulama firsatı elde etme ve deneyim kazanmaya da yardımcı olur (Spear, 2000).

Sosyal beceri yetersizliği olan ergenlerde akran reddi, izolasyon, sınırlı sosyal aktivite, zayıf sosyal destek gibi olumsuz sosyal durumlarla ile karş1laşılabilir. Bu bireylerde yüksek seviyede yalnızlık ve kalitesiz arkadaşlık ilişkileri olabilir, eğer özel bir akran grubu içine girmezlerse ya durum üzerinde daha fazla kontrol sağlamaya çalışırlar ya da geri adım atarlar. Gruba uyum sağlamada başarısız olup geri çekilen ergenler, depresyon veya anksi- 
yete için yüksek risk altındadırlar. Saldırganlık veya davranış problemleri gibi dışsallaştırıcı davranışlar da sergileyebilirler. Ayrıca zorbalık, ilişkisel saldırganlık ve sosyal dışlamaya da rastlanabilir (Braddock ve ark., 2015). Sonuç olarak, sosyal beceri yetkinliği ile ilgili problem yaşayan ergenler, arkadaşlık kurma, sürdürme ve akranlarına bağlanmada problemler yaşayıp davranış problemleri sergileyebilirler.

DiTommaso, Brannen-McNulty, Ross ve Burges (2003) çalışmaların$\mathrm{da}$, güvenli bağlanan bireylerin sosyal beceri düzeyinin yüksek olduğunu saptamışlardır. Kumru, Carlo ve Edwards (2004) çalışmalarında, anne-baba ve akran bağlılıkları, toplumsal değerler, ahlakî muhakeme, başkalarının bakış açısını anlama ve empati değişkenlerinin ergenlerin olumlu sosyal davranışlarını anlamlı olarak yordadığına vurgulamışlardır. Rice, Cunningham ve Young (1997) çalışmalarında, 16-18 yaşlarındaki ergenlerin bağlanma güvenliğinin sosyal becerilerini arttırdığını saptamışlardır. Yapılan deneysel çalışmalar, bağlanma ile çatışmaları çözümleme, eleştirilere açık olma, eleştiri yapma gibi olumlu sosyal becerilerin ilişkili olduğunu göstermiştir (akt; Allen ve ark., 2002). Ergenler çekirdek aileleri içerisinde edindikleri sosyal becerileri akranları ile olan sosyal becerilerine kolaylıkla uyarlayabilirler (Engels, Finkenauer ve Meeus, 2001). Ebeveynlere bağlanma, ergenlerin romantik ilişkileri ve samimi dostlukları gibi diğer sosyal ilişkilerini etkileyebilir. Ergenlerin sosyal becerileri ve ebeveyne bağlanma güvenliğinin incelenmesinin, sosyal gelişimlerinin sağlanmasına yönelik çalışmalara ışık tutacağ1 düşünülmektedir. Konuyla ilgili Türkiye’de ve Dünya'da sosyal beceriler ve bağlanma konularının birbirleriyle olan ilişkisini inceleyen araştırmaların oldukça sınırlı sayıda olduğu görülmüştür. Bu nedenle bu çalışmada 12-14 yaş arası ergenlerin sosyal beceri düzeyi ile ebeveynlerine bağlanma güvenliği arasındaki ilişkiyi incelemek amaçlanmıştır. Bu genel amaç doğrultusunda aşağıdaki sorulara cevap aranmıştır:

- Ergenlerin sosyal beceri düzeyi ve bağlanma güvenliği ile sınıf düzeyi, cinsiyet, kardeş sayısı, doğum sırası arasında fark var mıdır?

- Ergenlerin sosyal beceri düzeyi ve bağlanma güvenliği ile ebeveynlerinin yaş, öğrenim durumu, meslekleri arasında fark var m1dir?

- Ergenlerin sosyal beceri düzeyi ile ebeveynlerine bağlanma güvenliği arasında fark var mıdır? 


\section{Yöntem}

\section{Araştırmanın Modeli}

$\mathrm{Bu}$ çalışma betimsel tarama modelindedir. Betimsel taramalar bir konuya ya da olaya ilişkin katılımcıların görüşlerinin ilgi, beceri, yetenek, tutum vb. özelliklerinin belirlendiği genellikle diğer araştırmalara göre görece daha büyük örneklemler üzerinde yapılmaktadır (Büyüköztürk, Çakmak, Akgün, Karadeniz ve Demirel, 2013). Çalışmada ergenlerin sınıf düzeyi, cinsiyeti, kardeş sayısı, doğum sırası ve ebeveynlerin yaş, öğrenim durumu, meslekleri bağımsız değişkenler; ergenlerin sosyal beceri düzeyi ve bağlanma güvenliği ise bağımlı değişkenler olarak ele alınmıştır.

\section{Evren ve Örneklem}

Araştırmanın evrenini 2014-2015 eğitim öğretim yılında Karabük İl merkezinde Millı̂ Eğitim Bakanlığına bağlı resmî ilköğretim okullarının 6, 7 ve 8. sınıflarında öğrenim gören 12-14 yaş grubu 4614 ergen oluşturmuştur. $\mathrm{Bu}$ evrenden basit rasgele örnekleme yoluyla seçilen ve çalışmaya katılmaya gönüllü 349 ergen örneklem grubunu oluşturmuştur. Ergenlerin, \%35.8'i 8. sinıf, \%32.1'i 7. sinıf, \%32.1'i ise 6. sinıfta; \%52.4'ü erkek, \%47.6'sı kız; \%89'u 2-4 kardeş, \%9'u tek çocuk, \%2'si 5 ve üstü kardeşe sahip; \%43.7'si ilk çocuk, \%35.5'i son çocuk, \% 20.8'i ise ortanca çocuktur. Ergenlerin annelerinin \%47.3'ü 36-40 yaş, \%29.9'u 41-45 yaş, \%23.4'ü 31-35 yaş, \%5.4'ü 25-30 yaş aralığında; babalarının \%51'i 41-45 yaş, \%36.9'u 36-40 yaş, \%11.3'ü 31-35 yaş, \% 0.8'i ise 25-30 yaş aralığındadır. Annelerin \%40.6's1 ilkokul, \%23.7’si ortaokul, \%27.3'ü lise, \%8,7’si lisans veya lisansüstü mezunu; babaların \%22.5'i ilkokul, \%21.1'i ortaokul, \%36.1'i lise, \%20.3’ü lisans veya lisansüstü mezunudur. Annelerin \%71.5'i çalışmamakta, \%11.8’i serbest meslek sahibi, \%7.9'u memur, \%6.2'si iş̧̧i, \%1.7'si diğer meslek grubunda (mühendis, doktor, avukat vb.); babaların \%37.2'si işçi, \%27.3'ü serbest meslek sahibi, \%21.1'i memur, \%6.2'si diğer meslek grubunda (mühendis, doktor, avukat vb.) ve \%1.7'si çalışmamaktadır.

\section{Verilerin Toplanması}

Araştırmada verilerin toplanmasında "Matson Çocuklarda Sosyal Becerileri Değerlendirme Ölçeği (MESSY)", "Ebeveyn ve Akrana Bağlanma Ölçeği (EABE)" ve "Kişisel Bilgi Formu" kullanılmıştır.

Matson Çocuklarda Sosyal Becerileri Değerlendirme Ölçeği (MESSY): 12-14 yaş grubunun sosyal beceri düzeyini ölçmek için Matson, Rotatory ve Hessel (1983) tarafından geliştirilmiştir. MESSY öğrenci formunun Türkçeye uyar- 
lanması Bacanlı ve Erdoğan (2003) tarafindan yapılmıştır. Toplam 47 maddeden oluşan ölçek, "Bana hiç uygun değil-1 puan”, "Bana pek uygun değil-2 puan”, “Bana biraz uygun-3 puan”, "Bana oldukça uygun-4 puan”, “Bana tamamen uygun-5 puan" şeklinde 5'li likert tipindedir. Olumlu sosyal davranışlar ve olumsuz sosyal davranışlar olmak üzere iki alt boyut bulunmaktadır. Geçerlik çalışmasında faktör analizi, benzer ölçek geçerliği, güvenirlik çalışmasında ise test-tekrar-test güvenirliği ve iç tutarlık katsayısına bakılmıştır. Ölçeğin 41 maddesinin madde toplam korelasyonları .30'un üstünde bulunmuştur. Ölçekten alınabilecek en düşük puan 47, en yüksek puan 235'tir.

Ebeveyn ve Akrana Bağlanma Ölçeği (EABE): 11-21 yaş grubundaki çocuk ve gençlerin, anne-baba ve akranlarına olan bağlılıklarını ölçmek amacıyla Armsden ve Greenberg (1987) tarafından geliştirilmiştir. "Asla-1 puan” "Daima-5 puan" şeklinde 5'li likert tipindeki ölçeğin iç tutarlılık katsayısı Ebeveyne Bağlanma alt boyutu için .82, Akran Bağlllı̆̆1 alt boyutu için .74'tür. Kumru (2002) tarafından Türkçeye uyarlanan ölçekten, bir madde çıkarılmış ve 12 maddelik kısa formu kullanılmıştır (Kumru, Carlo ve Edwards, 2004).

Kişisel Bilgi Formu: Araştırmacı tarafından geliştirilmiştir. Ergenlerin cinsiyeti, doğum sırası, kardeş sayısı, anne-babalarının öğrenim ve çalışma durumu, mesleği, aile tipi ile ilgili bilgileri saptamaya yönelik sorular yer almaktadır.

\section{Verilerin Analizi}

Verilerin analizi SPSS 20.00 paket programı ile yapılmıştır. Değişkenlerin normallik dağılımı Shapiro Wilk's ile incelenmiş, verilerin analizinde değişkenler arasındaki farklar Mann Whitney U ve Kruskal Wallis-H Testleri kullanılmıştır. İki ölçek puanları arası farkın incelenmesinde Spearman’s Brown korelasyon katsayısından yararlanılmıştır. Sonuçlar yorumlanırken anlamlılık düzeyi olarak 0.05 kullanılmıştır.

\section{Bulgular}

Çalışmanın ilk alt problemine ilişkin olarak, ergenlerin sınıf düzeyi, cinsiyet, kardeş sayısı, doğum sırası ile bağlanma güvenliği arasında fark olup olmadığına ilişkin bulgular Tablo 1'de, sosyal beceri düzeyi arasında fark olup olmadığına ilişkin bulgular Tablo 2'de verilmiştir. 
Tablo 1. Ergenlerin Sınıf, Cinsiyet, Kardeş Sayısı ve Doğum Sırasına Göre EABE Ebeveyn Bağlanma Alt Boyutu Kruskal Wallis-H Testi ve Mann Whitney U Testi Sonuçları

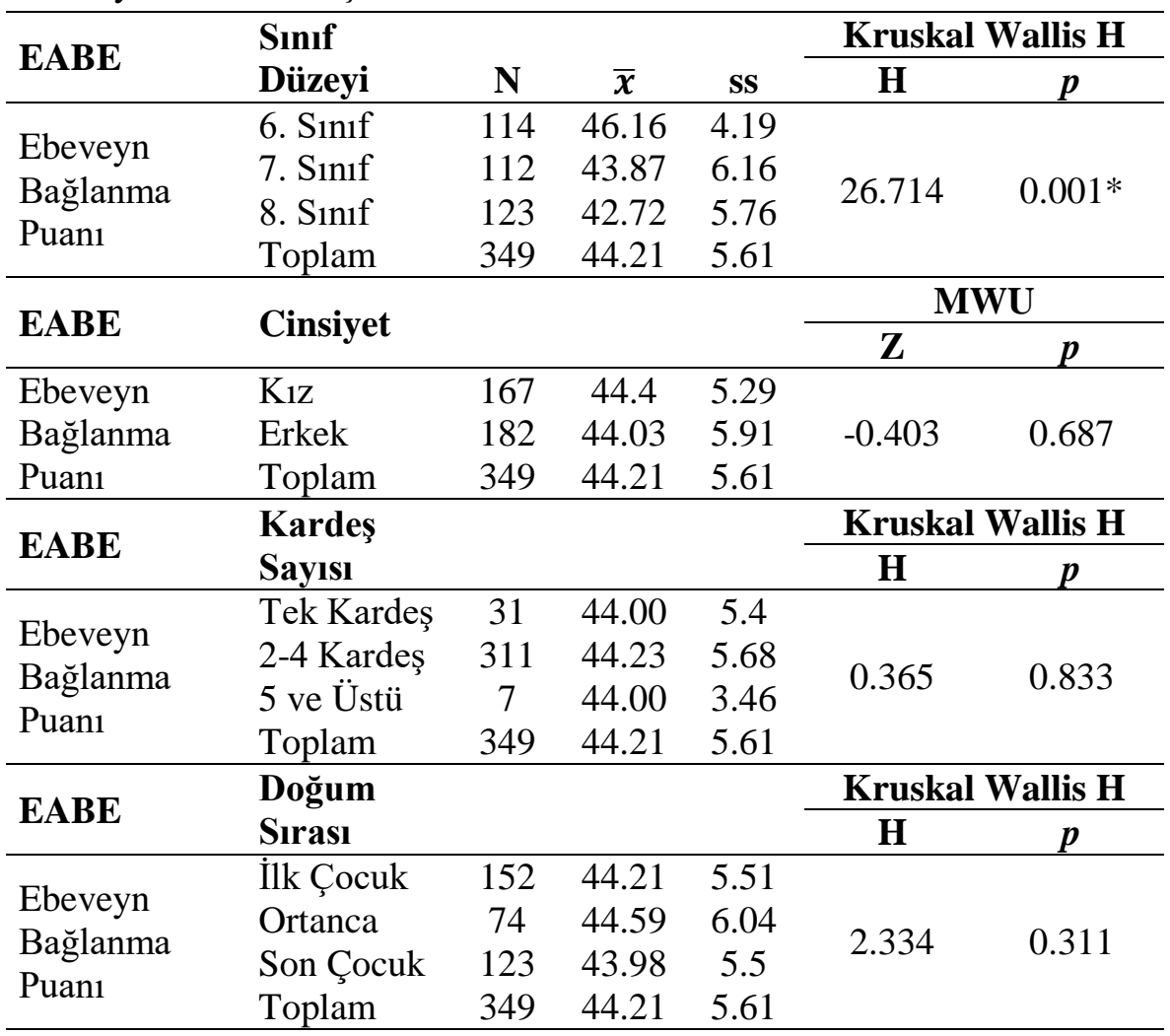

Tablo 1'e bakıldığında, ergenlerin sınıf düzeylerine göre EABE Ebeveyn Bağlanma alt ölçeği ortalama puanı arasında anlamlı fark vardır $(p<0.05)$. 6. siniflarin puan ortalamas1 $(\bar{x}=46.16), 7$. sinif $(\bar{x}=43.87)$ ve 8 . sınıfların aynı puanından ( $\bar{x}=42.72)$ daha yüksektir. Buna göre; ergenlerin yaşı arttıkça ebeveyn bağlanma güvenliğinin azaldığı söylenebilir. 
Tablo 2. Ergenlerin Sınıf, Cinsiyet, Kardeş Sayısı ve Doğum Sırasına Göre MESSY Kruskal Wallis-H Testi ve Mann Whitney U Testi Sonuçları

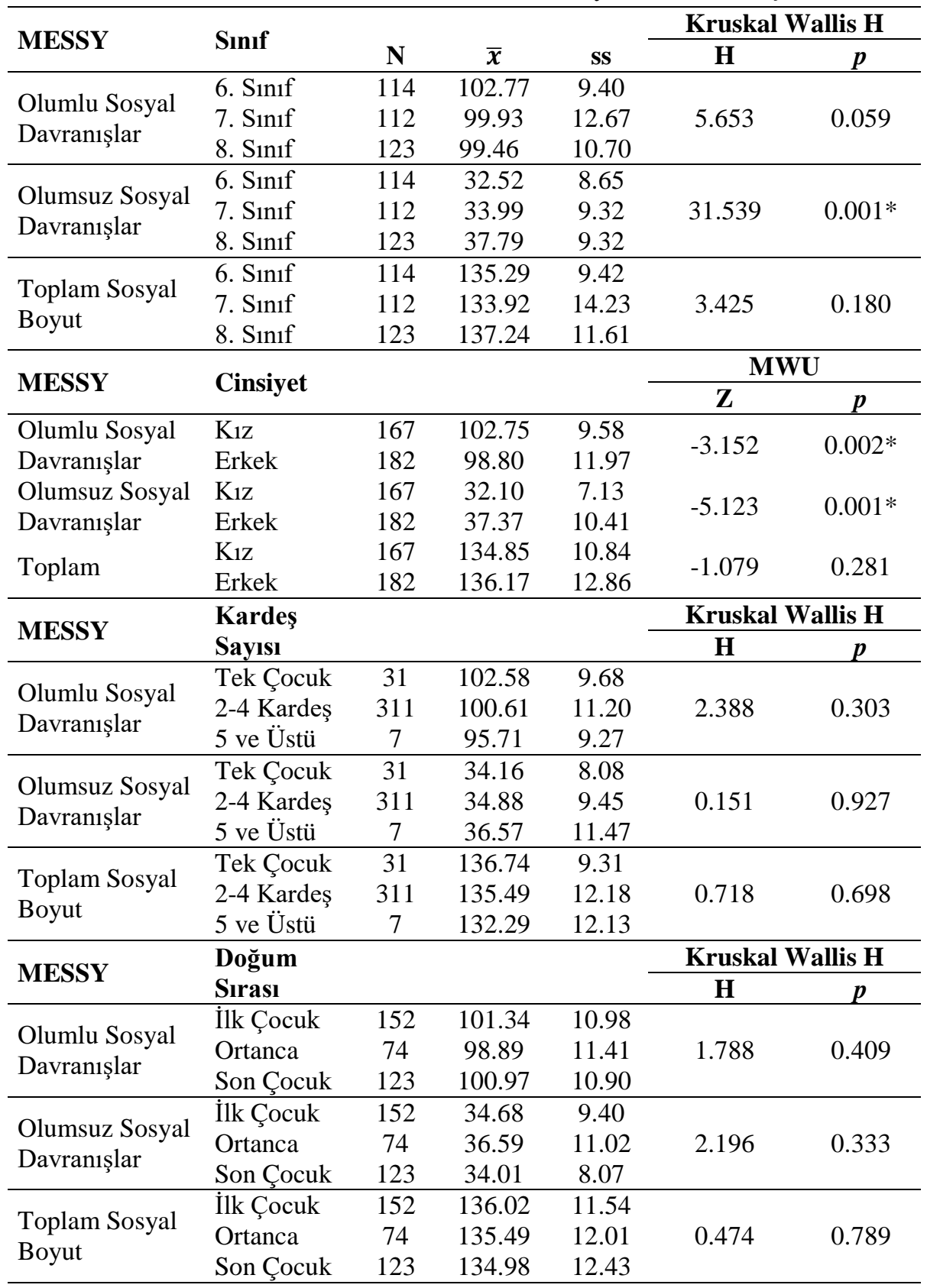
${ }^{*} p<0.05$ 
Tablo 2'ye göre, ergenlerin MESSY Olumlu Sosyal Davranış alt boyut ve toplam puan ortalamaları ile sınıf düzeyi arasında istatistiksel olarak anlamlı bir fark saptanmazken $(p>0.05)$, Olumsuz Sosyal Davranış alt boyut puan ortalamaları ile sınıf düzeyi arasında anlamlı bir fark saptanmıştır $(p<0.05)$. 8. sınıfların Olumsuz Sosyal Davranış puanları $(\bar{x}=37.49), 6$. sınıf $(\bar{x}=32.52)$ ve 7 . sinifların $(\bar{x}=33.99)$ puanlarından yüksektir. Ergenlerin Olumlu ve Olumsuz Sosyal Davranış alt boyut puanları ile cinsiyetleri arasında istatistiksel olarak anlamlı fark vardır $(p<0.05)$. Kizların Olumlu Sosyal Davranış alt boyut puanı $(\bar{x}=102.75)$, erkeklerin $(\bar{x}=98.80)$ puanından; erkeklerin Olumsuz Sosyal Davranış alt boyut puanı $(\bar{x}=37.37)$, kızların puanından $(\bar{x}=32.10)$ yüksektir. Ergenlerin kardeş sayısı ve doğum sırası MESSY alt ölçek ve toplam puanları arasında anlamlı fark yoktur ( $p>0.05)$. Buna göre; ergenlerin yaşı arttıkça olumsuz davranış sergileme durumlarının arttığı, kızların erkeklere döre daha olumlu sosyal davranışlar sergilediği söylenebilir. Kardeş sayısı ve doğum sırası değişkenlerinin ergenlerin sosyal becerilerine etki etmediği söylenebilir.

Çalışmanın ikinci alt problemine ilişkin olarak, ergenlerin ebeveynlerinin yaş, öğrenim durumu, meslekleri ile bağlanma güvenliği arasında fark olup olmadığına ilişkin bulgular Tablo 3'te, sosyal beceri düzeyi arasında fark olup olmadığına ilişkin bulgular Tablo 4'te verilmiştir.

Tablo 3'e göre ergenlerin anne ve babalarının öğrenim durumları ile ergenlerin ebeveyn bağlanma puan ortalamaları arasında istatistiksel olarak anlamlı fark vardır $(p<0.05)$. İlkokul mezunu olan annelerin puan ortalaması $(\bar{x}=43.21)$, ortaokul $(\bar{x}=45.13)$ ve lise mezunu olanların puan ortalamasindan $(\bar{x}=44.84)$, ilkokul mezunu olan babaların puan ortalaması $(\bar{x}=41.83)$ lise $(\bar{x}=45.30)$ ve lisans ve lisansüstü mezunu olanların puan ortalamasından ( $\bar{x}=44.89)$ düşüktür. Ergenlerin anne yaşları, baba yaşları, anne ve babalarının mesleği ile ebeveyn bağlanma puan ortalamaları arasında ise istatistiksel olarak anlamlı fark yoktur $(p>0.05)$. Buna göre; ebeveynleri ilkokul mezunu olan ergenlerin ebeveynlerine bağlanma güvenliğinin daha düşük olduğu, anne-baba yaşı ve mesleğinin ise bağlanma güvenliğini etkilemediği söylenebilir. 
Tablo 3. Ergenlerin Anne-Baba Yaş1, Öğrenim Durumu ve Mesleğine Göre EABE Ebeveyn Bağlanma Alt Boyutu Kruskal Wallis-H Testi ve Mann Whitney U Testi Sonuçları

\begin{tabular}{|c|c|c|c|c|c|c|}
\hline EABE & Anne Yaşı & $\mathbf{N}$ & $\bar{x}$ & ss & $\mathbf{H}$ & $p$ \\
\hline & 25-30 yaş & 19 & 44.68 & 7.07 & \multirow{5}{*}{3.742} & \multirow{5}{*}{0.291} \\
\hline Ebeveyn & $31-35$ yaş & 83 & 44.7 & 6.1 & & \\
\hline Bağlanma & $36-40$ yaş & 166 & 44.14 & 5.12 & & \\
\hline \multirow[t]{2}{*}{ Puanı } & $41-45$ yaş & 81 & 43.74 & 5.75 & & \\
\hline & Toplam & 349 & 44.21 & 5.61 & & \\
\hline EABE & \multicolumn{6}{|c|}{ Anne Öğrenim Durumu } \\
\hline & İlkokul Mezunu ve Altı & 137 & 43.21 & 6.03 & \multirow{5}{*}{7.932} & \multirow{5}{*}{$0.047^{*}$} \\
\hline Ebeveyn & Ortaokul mezunu & 84 & 45.13 & 5.83 & & \\
\hline Bağlanma & Lise mezunu & 97 & 44.84 & 5.01 & & \\
\hline \multirow[t]{2}{*}{ Puanı } & Lisans ve Lisans Ü. & 31 & 44.16 & 4.27 & & \\
\hline & Toplam & 349 & 44.21 & 5.61 & & \\
\hline EABE & \multicolumn{6}{|l|}{ Anne Meslek } \\
\hline & Çalışmıyor & 250 & 44.26 & 5.64 & \multirow{5}{*}{$\begin{array}{l}0.927 \\
0.819\end{array}$} & \\
\hline Ebeveyn & İşçi & 22 & 43.27 & 5.46 & & \\
\hline Bağlanma & Memur & 37 & 44.46 & 4.49 & & \\
\hline \multirow[t]{2}{*}{ Puanı } & Serbest meslek & 40 & 44.2 & 6.54 & & \\
\hline & Toplam & 349 & 44.21 & 5.61 & & \\
\hline EABE & \multicolumn{6}{|l|}{ Baba Yaşı } \\
\hline \multirow{4}{*}{$\begin{array}{l}\text { Ebeveyn } \\
\text { Bağlanma } \\
\text { Puanı }\end{array}$} & 35 yaş altı & 43 & 43.23 & 7.57 & \multirow{4}{*}{0.004} & \multirow{4}{*}{0.998} \\
\hline & 36-40 yaş & 131 & 44.31 & 5.27 & & \\
\hline & $41-45$ yaş & 175 & 44.38 & 5.31 & & \\
\hline & Toplam & 349 & 44.21 & 5.61 & & \\
\hline EABE & \multicolumn{6}{|c|}{ Baba Öğrenim Durumu } \\
\hline & İlkokul & 76 & 41.83 & 6.53 & \multirow{5}{*}{16.726} & \multirow{5}{*}{$0.001^{*}$} \\
\hline Ebeveyn & Ortaokul & 73 & 44.11 & 5.87 & & \\
\hline Bağlanma & Lise & 128 & 45.30 & 5.14 & & \\
\hline \multirow[t]{2}{*}{ Puan1 } & Lisans ve Lisans Ü. & 72 & 44.89 & 4.29 & & \\
\hline & Toplam & 349 & 44.21 & 5.61 & & \\
\hline \multirow[t]{2}{*}{ EABE } & Baba Meslek & & & & & \\
\hline & Çalışmiyor & 131 & 43.93 & 5.48 & \multirow{5}{*}{1.320} & \multirow{5}{*}{0.724} \\
\hline Ebeveyn & İşçi & 96 & 44.47 & 4.84 & & \\
\hline Bağlanma & Memur & 27 & 43.59 & 7.34 & & \\
\hline \multirow[t]{2}{*}{ Puanı } & Serbest Meslek & 95 & 44.51 & 6.02 & & \\
\hline & Toplam & 349 & 44.21 & 5.61 & & \\
\hline
\end{tabular}


Tablo 4. Ergenlerin Anne-Baba Yaşı, Öğrenim Durumu ve Mesleğine Göre MESSY Kruskal Wallis-H Testi ve Mann Whitney U Testi Sonuçları

\begin{tabular}{|c|c|c|c|c|c|c|}
\hline MESSY & Anne Yaşı & $\mathbf{N}$ & $\bar{x}$ & ss & $\mathbf{H}$ & $p$ \\
\hline \multirow{4}{*}{$\begin{array}{l}\text { Olumlu } \\
\text { Sosyal } \\
\text { Davranışlar }\end{array}$} & 25-30 yaş & 19 & 94.26 & 13.96 & \multirow{4}{*}{7.861} & \multirow{4}{*}{$0.049 *$} \\
\hline & $31-35$ yaş & 83 & 101.99 & 10.67 & & \\
\hline & $36-40$ yaş & 166 & 100.36 & 11.32 & & \\
\hline & 41-45 yaş & 81 & 101.54 & 9.71 & & \\
\hline \multirow{4}{*}{$\begin{array}{l}\text { Olumsuz } \\
\text { Sosyal } \\
\text { Davranışlar }\end{array}$} & 25-30 yaş & 19 & 38.68 & 12.15 & \multirow{4}{*}{4.568} & \multirow{4}{*}{0.206} \\
\hline & $31-35$ yaş & 83 & 33.67 & 9.15 & & \\
\hline & $36-40$ yaş & 166 & 34.9 & 9.24 & & \\
\hline & $41-45$ yaş & 81 & 35.04 & 8.98 & & \\
\hline \multirow{4}{*}{$\begin{array}{l}\text { Toplam } \\
\text { Sosyal } \\
\text { Boyut }\end{array}$} & $25-30$ yaş & 19 & 132.95 & 15.78 & \multirow{4}{*}{1.168} & \multirow{4}{*}{0.761} \\
\hline & 31-35 yaş & 83 & 135.66 & 11.21 & & \\
\hline & $36-40$ yaş & 166 & 135.27 & 12.31 & & \\
\hline & $41-45$ yaş & 81 & 136.58 & 10.93 & & \\
\hline MESSY & Anne Ö̆ğrenim & & & & & \\
\hline \multirow{4}{*}{$\begin{array}{l}\text { Olumlu } \\
\text { Sosyal } \\
\text { Davranışlar }\end{array}$} & İlkokul & 137 & 99.35 & 11.9 & \multirow{4}{*}{2.297} & \multirow{4}{*}{0.513} \\
\hline & Ortaokul & 84 & 101.01 & 10.28 & & \\
\hline & Lise & 97 & 101.68 & 11.07 & & \\
\hline & Lisans ve Lisans Ü. & 31 & 102.65 & 8.7 & & \\
\hline \multirow{4}{*}{$\begin{array}{l}\text { Olumsuz } \\
\text { Sosyal } \\
\text { Davranışlar }\end{array}$} & İlkokul & 137 & 35.66 & 9.57 & \multirow{4}{*}{4.237} & \multirow{4}{*}{0.237} \\
\hline & Ortaokul & 84 & 33.90 & 9.19 & & \\
\hline & Lise & 97 & 33.74 & 8.02 & & \\
\hline & Lisans ve Lisans Ü. & 31 & 37.26 & 12.07 & & \\
\hline \multirow{4}{*}{$\begin{array}{l}\text { Toplam } \\
\text { Sosyal } \\
\text { Boyut }\end{array}$} & İlkokul & 137 & 135.01 & 12.77 & \multirow{4}{*}{3.347} & \multirow{4}{*}{0.341} \\
\hline & Ortaokul & 84 & 134.92 & 10.89 & & \\
\hline & Lise & 97 & 135.42 & 11.44 & & \\
\hline & Lisans ve Lisans Ü. & 31 & 139.90 & 12.03 & & \\
\hline MESSY & Anne Meslek & & & & & \\
\hline \multirow{4}{*}{$\begin{array}{l}\text { Olumlu } \\
\text { Sosyal } \\
\text { Davranışlar }\end{array}$} & Ev hanımı & 250 & 100.41 & 11.48 & \multirow{4}{*}{0.859} & \multirow{4}{*}{0.835} \\
\hline & İşçi & 22 & 103.00 & 6.6 & & \\
\hline & Memur & 37 & 102.03 & 9.54 & & \\
\hline & Serbest meslek & 40 & 99.92 & 11.62 & & \\
\hline \multirow{4}{*}{$\begin{array}{l}\text { Olumsuz } \\
\text { Sosyal } \\
\text { Davranışlar }\end{array}$} & Ev hanımı & 250 & 34.52 & 9.27 & \multirow{4}{*}{3.156} & \multirow{4}{*}{0.368} \\
\hline & İşçi & 22 & 36.82 & 8.01 & & \\
\hline & Memur & 37 & 36.46 & 11.45 & & \\
\hline & Serbest meslek & 40 & 34.35 & 8.46 & & \\
\hline \multirow{4}{*}{$\begin{array}{l}\text { Toplam } \\
\text { Sosyal } \\
\text { Boyut }\end{array}$} & Ev hanımı & 250 & 134.93 & 11.69 & \multirow{4}{*}{4.885} & \\
\hline & İşçi & 22 & 139.82 & 9.91 & & 0.183 \\
\hline & Memur & 37 & 138.49 & 13.33 & & \\
\hline & Serbest meslek & 40 & 134.28 & 12.64 & & \\
\hline
\end{tabular}




\begin{tabular}{|c|c|c|c|c|c|c|}
\hline MESSY & Baba Yaşı & & & & & \\
\hline Olumlu & 35 yaş altı & 43 & 96.49 & 13.38 & \multirow{3}{*}{5.994} & \multirow{3}{*}{$0.049 *$} \\
\hline Sosyal & $36-40$ yaş & 131 & 100.96 & 10.92 & & \\
\hline Davranışlar & 41-45 yaş & 175 & 101.52 & 10.34 & & \\
\hline Olumsuz & 35 yaş altı & 43 & 35.58 & 11.26 & \multirow{3}{*}{0.028} & \multirow{3}{*}{0.986} \\
\hline Sosyal & 36-40 yaş & 131 & 34.64 & 8.83 & & \\
\hline Davranışlar & 41-45 yaş & 175 & 34.82 & 9.28 & & \\
\hline Toplam & 35 yaş altı & 43 & 132.07 & 14.2 & \multirow{3}{*}{3.109} & \multirow{3}{*}{0.211} \\
\hline Sosyal & $36-40$ yaş & 131 & 135.6 & 11.11 & & \\
\hline Boyut & $41-45$ yaş & 175 & 136.34 & 11.85 & & \\
\hline MESSY & Baba Öğrenim & & & & & \\
\hline \multirow{4}{*}{$\begin{array}{l}\text { Olumlu } \\
\text { Sosyal } \\
\text { Davranışlar }\end{array}$} & İlkokul & 76 & 96.46 & 12.47 & \multirow{4}{*}{7.932} & \multirow{4}{*}{$0.001^{*}$} \\
\hline & Ortaokul & 73 & 101.04 & 9.47 & & \\
\hline & Lise & 128 & 101.09 & 11.28 & & \\
\hline & Lisans ve Lisans Ü. & 72 & 104.08 & 9.22 & & \\
\hline \multirow{4}{*}{$\begin{array}{l}\text { Olumsuz } \\
\text { Sosyal } \\
\text { Davranışlar }\end{array}$} & İlkokul & 76 & 36.21 & 8.59 & \multirow{4}{*}{7.23} & \multirow{4}{*}{0.065} \\
\hline & Ortaokul & 73 & 35.11 & 8.9 & & \\
\hline & Lise & 128 & 33.95 & 10.25 & & \\
\hline & Lisans ve Lisans Ü. & 72 & 34.74 & 8.92 & & \\
\hline \multirow{4}{*}{$\begin{array}{l}\text { Toplam } \\
\text { Sosyal } \\
\text { Boyut }\end{array}$} & İlkokul & 76 & 132.67 & 12.47 & \multirow{4}{*}{7.932} & \multirow{4}{*}{$0.001^{*}$} \\
\hline & Ortaokul & 73 & 136.15 & 11.64 & & \\
\hline & Lise & 128 & 135.05 & 12.3 & & \\
\hline & Lisans ve lisansüstü & 72 & 138.82 & 10.28 & & \\
\hline MESSY & Baba Meslek & & & & & \\
\hline \multirow{4}{*}{$\begin{array}{l}\text { Olumlu } \\
\text { Sosyal } \\
\text { Davranışlar }\end{array}$} & İşsiz & 131 & 100.05 & 10.98 & \multirow{4}{*}{1.778} & \multirow{4}{*}{0.620} \\
\hline & İşçi & 96 & 101.47 & 11.43 & & \\
\hline & Memur & 27 & 100.37 & 12.45 & & \\
\hline & Serbest meslek & 95 & 100.88 & 10.46 & & \\
\hline \multirow{4}{*}{$\begin{array}{l}\text { Olumsuz } \\
\text { Sosyal } \\
\text { Davranışlar }\end{array}$} & İşsiz & 131 & 35.01 & 8.93 & \multirow{4}{*}{2.401} & \multirow{4}{*}{0.493} \\
\hline & İşçi & 96 & 34.92 & 11.11 & & \\
\hline & Memur & 27 & 37.04 & 10.25 & & \\
\hline & Serbest meslek & 95 & 33.94 & 7.6 & & \\
\hline \multirow{4}{*}{$\begin{array}{l}\text { Toplam } \\
\text { Sosyal } \\
\text { Boyut }\end{array}$} & İşsiz & 131 & 135.05 & 11.5 & \multirow{4}{*}{1.820} & \multirow{4}{*}{0.610} \\
\hline & İşçi & 96 & 136.39 & 12.96 & & \\
\hline & Memur & 27 & 137.41 & 12.64 & & \\
\hline & Serbest meslek & 95 & 134.82 & 11.31 & & \\
\hline
\end{tabular}

Tablo 4 incelendiğinde anne yaşına göre ergenlerin Olumlu Sosyal Davranış alt boyutu puan ortalamaları istatistiksel olarak anlamlı fark göstermiştir $(p<0.05)$. Yaşı 31-35 olanların puan ortalaması ( $\bar{x}=101.99), 25-30$ yaş grubunda olanların puan ortalamasından $(\bar{x}=94.26)$ yüksektir. Olumsuz 
Sosyal Davranış alt boyutu puan ortalaması ve MESSY toplam puan ortalaması ile anne yaşları arasında istatistiksel olarak anlamlı fark yoktur $(p>0.05)$. Babaların yaşlarına göre Ergenlerin Olumlu Sosyal Davranış alt boyut puan ortalamaları istatistiksel olarak anlamlı bir fark göstermiştir $(p<0.05)$. Yaşı 35 ve alt1 olanların puan ortalaması ( $\bar{x}=96.49), 36-40$ yaş grubunda olanların puan ortalamasından $(\bar{x}=100.96)$ düşüktür. Olumsuz Sosyal Davranış alt boyutu puan ortalamas1 ve MESSY toplam puan ortalaması ile baba yaşı arasında ise istatistiksel olarak anlamlı fark yoktur $(p>0.05)$. Annelerin öğrenim durumlarına göre Ergenlerin Olumlu, Olumsuz Sosyal Davranış alt boyut puan ortalamaları ve MESSY toplam puan ortalamaları istatistiksel olarak anlamlı bir fark göstermemiştir $(p>0.05)$. Babaların öğrenim durumuna göre Ergenlerin Olumlu Sosyal Davranışlar alt boyutu puan ortalamaları istatistiksel olarak anlamlı bir fark göstermiştir $(p<0.05)$. İlkokul mezunu olanların ortalaması $(\bar{x}=96.46)$, lise $(\bar{x}=101.09)$ ve lisans ve lisansüstü mezunu olanların ortalamasından $(\bar{x}=104.08)$ düşüktür. Babalarının öğrenim durumlarına göre ergenlerin Olumsuz Sosyal Davranış alt boyut puan ortalamaları istatistiksel olarak anlamlı bir farklılık göstermemiştir $(p>0.05)$. Babaların öğrenim durumuna göre ergenlerin MESSY toplam puan ortalamaları ise istatistiksel olarak anlamlı bir fark göstermiştir $(p<0.05)$. İlkokul mezunu olanların puan ortalaması ( $\bar{x}=132.67)$, lisans ve lisansüstü mezunu olanların puan ortalamasından ( $\bar{x}=138.82)$ düşüktür. Anne ve babaların meslekleri ile ergenlerin Olumlu, Olumsuz Sosyal Davranış alt boyut ve MESSY toplam puan ortalamaları arasında istatistiksel olarak anlamlı bir fark yoktur ( $p>0.05$ ). Buna göre; annesi 31-35 yaş aralığında ve babası 36-40 yaş aral1ğında olan ergenlerin daha olumlu sosyal davranışlar sergiledikleri söylenebilir. Anne öğrenim durumu ve anne-baba mesleklerinin ergenlerin sosyal beceri düzeyini etkilemediği, baba öğrenim durumu lisansüstü olan ergenlerin sosyal beceri düzeylerinin daha iyi olduğu söylenebilir.

Çalışmanın üçüncü alt problemine ilişkin olarak, ergenlerin sosyal beceri düzeyi ile ebeveynlerine bağlanma güvenliği arasında fark olup olmadığ Tablo 5'te verilmiştir.

Tablo 5'te görüleceği gibi, ergenlerin olumlu sosyal davranış puanları ile ebeveyn bağlanma puanları arasında istatistiksel olarak anlamlı bir ilişki vardır $(p<0.05)$. Bu ilişki pozitif yönde zayıf bir ilişkidir $(r=0.245)$. Olumsuz sosyal davranış puanları ile ebeveyn bağlanma puanları arasında istatistiksel olarak anlamlı bir ilişki olduğu görülmektedir $(p<0.05)$. Bu ilişki negatif 
yönde zayıf bir ilişkidir ( $\mathrm{r}=-0.182)$.

Tablo 5. Ergenlerin Ebeveynlerine Bağlanma Güvenliği ile Sosyal Beceri Düzeyleri Arasındaki İlişkiye Dair Spearman Korelasyon Testi Sonuçları

\begin{tabular}{lccc}
\hline & & $\begin{array}{c}\text { Olumlu Sosyal } \\
\text { Davranışlar }\end{array}$ & $\begin{array}{c}\text { Olumsuz Sosyal } \\
\text { Davranışlar }\end{array}$ \\
\hline Ebeveyn & $\mathrm{r}$ & 0.245 & -0.182 \\
Bağlanma & $p$ & 0001 & 0.001 \\
Puanı & $\mathrm{N}$ & 349 & 349 \\
\hline
\end{tabular}

Toplam sosyal davranış puanları ile ebeveyn bağlanma puanları arasında ise anlamlı bir ilişki görülmemektedir $(p>0.05)$. Buna göre; ergenlerin ebeveyn bağlanma puanları arttıkça olumlu sosyal davranışlarının arttığı ve olumsuz sosyal davranışlarının azaldığı söylenebilir.

\section{Tartışma}

Ergenlerin sosyal beceri düzeyi ile ebeveynlerine bağlanma güvenliği arasındaki ilişkiyi belirlemek amacıyla yapılan bu araştırmada, ergenlerin yaşı arttıkça ebeveyn bağlanma güvenliğinin azaldığı belirlenmiştir. Bu durum yaş ilerledikçe gelişimsel ihtiyaçların giderilmesinde ebeveyne bağımlılığın azalması ile açıklanabilir. Bu bulguyla benzer olarak Lieberman, Doyle ve Markiewicz (1999) çalışmalarında orta çocukluk dönemi boyunca yaş ile birlikte "bağımlılık" ihtiyacının azaldığı belirlemişlerdir. Ergenlerin Ebeveyn Bağlanma alt ölçek puan ortalamaları ile cinsiyet, kardeş sayısı ve doğum sırası arasında anlamlı bir fark görülmemiştir. Seven (2006) çalışmasında cinsiyet ile anne ve babaya bağlanma arasında istatiksel olarak anlamlı bir ilişki saptamamıştır. Tanış (2014) tarafından yapılan bir başka çalışmada kardeş sayısı ile bağlanma stilleri arasında istatistiksel olarak anlamlı bir fark olmadığ 1 saptanmıştır. Blehar (1974) tarafından yapılan bir araştırmada ilk ve son doğan çocukların anneye bağlanma güvenliği arasındaki fark anlamlı bulunmamıștır. Anne ve babaların çocuklarına karşı tutum ve davranıșları günümüzde çocuğun cinsiyetinden, kardeş sayısı ve doğum sırasından ziyade çocuğun özellikleri ile kendi kişilik ve demografik özelliklerinden etkilenebilmektedir. Bu bulguların araştırma bulgularını desteklediği söylenebilir.

Çalışmada, ergenlerin yaşı arttıkça olumsuz davranış sergileme durumlarının arttığı, kızların erkeklere döre daha olumlu sosyal davranışlar sergilediği belirlenmiştir. Kardeş sayısı ve doğum sırası değişkenlerinin ergenlerin sosyal becerilerine etki etmediği belirlenmiştir. Ergenlerde yaş ilerledikçe daha fazla bağımsızlaşma isteği ve buna bağlı olarak da kurallara 
uymayı tercih etmeyip olumsuz davranışlar gösterme eğiliminin olduğu bilinen bir gerçektir (Elliott, Barnard ve Gresham, 1989). Ergenlerin olumsuz sosyal davranış ortalamalarının yaşla birlikte artışı, çevrenin ve ailenin ergenlerden beklentileri, girilen sosyal ortamlar ve bu ortamlardaki ilişkilerin yapısı, geçirilen sosyal-duygusal değişimler, akademik zorlukların artması ve yaşanılan duygu durum dalgalanmalarından kaynaklanabilir. Kızların Olumlu Sosyal Davranış alt boyut puanlarının, erkeklerin puanından; erkeklerin Olumsuz Sosyal Davranış alt boyut puanlarının ise kızların puanından anlamlı olarak daha yüksek olduğu saptanmıştır. Jamyang-Tshering (2004) tarafından yapılan araştırmada, kızların erkeklerden daha fazla olumlu sosyal davranış gösterdikleri belirtilmiştir. Erkeklerin kızlara göre daha fazla olumsuz davranışlar sergilemesi ebeveynlerin çocuk yetiştirme tutumlarının çocukların cinsiyetine göre değişmesi, cinsiyet rolü eğitimleri, toplum ve ailenin kız ve erkeklerden beklentilerinin farklı olmasından (Bacanlı ve Erdoğan, 2003) kaynaklanabilir.

Çalışmada ebeveynleri ilkokul mezunu olan ergenlerin ebeveynlerine bağlanma güvenliğinin daha düşük olduğu, anne-baba yaşı ve mesleğinin ise bağlanma güvenliğini etkilemediği belirlenmiştir. Yapılan benzer çalışmaların çalışma bulgularını desteklediği görülmektedir (Cassidy, 1988; Keler, 2008; Seven, 2006; Sümer ve Şendağ, 2009). Woodworth ve arkadaşları (1996) tarafından yapılan bir çalışmada, babanın eğitim düzeyinin babanın bakıma katılması ve bebeğine bağlanmasını etkilediği saptanmıştır. Nkwake (2009) öğrenim düzeyi yüksek babaların çocuk bakımı konusunda eşitlikçi bir görüsse sahip olduklarını, bunun yanında düşük öğrenim düzeyinde olanların geleneksel görüşe sahip olduklarını ve bebeğin fiziksel bakımının annenin işi olduğunu düşündüklerini vurgulamıştır. Bu bulguların araştırma bulguları ile benzerlik gösterdiği, babanın öğrenim düzeyi yükseldikçe ergenin bağlanmasına olumlu katkı sağladığı söylenebilir. López-Turley (2003) çalışmasında düşük test skorları alan ve davranış problemleri olan çocukların bu durumlarının annelerinin annelik yaşının genç olması ile değil, yetiştirilme tutumlarıyla ile ilgili olduğunu saptamıştır. Dinç (2014) yaptığı çalışmada bağlanma puanı ile babanın yaşı arasında anlamlı bir ilişki saptamamıştır. $\mathrm{Bu}$ çalışmalar araştırmanın bulgularını destekler niteliktedir.

Çalışmada, annesi 31-35 yaş aralığında ve babası 36-40 yaş aralığında olan ergenlerin daha olumlu sosyal davranışlar sergiledikleri, anne öğrenim durumu ve anne-baba mesleklerinin ergenlerin sosyal beceri düzeyini etki- 
lemediği, baba öğrenim durumu lisansüstü olan ergenlerin sosyal beceri düzeylerinin daha iyi olduğu saptanmıştır. Anne ile çocuk arasında kurulan sağlıklı iletişim ve etkileşimin çocuğun sosyal ilişkilerinin gelişmesinde rolü büyüktür. Annelerin sağlıklı tutum sergilemeleri büyük oranda onların kendi içlerinde dengeli, kendileriyle barışık, huzurlu bireyler olmaları (Çağdaş, 2012) ve ebeveynlik rollerine değer vermeleri ile ilişkili olduğu söylenebilir. Dolayısıyla çocuğun sosyal beceri gelişiminde annenin yaşından ziyade ebeveynlik uygulamalarının daha önemli olduğu düşünülebilir. MacDonald (1987)'a göre yaşı büyük olan babalar yaşı daha genç olan babalara göre daha sıcak, iyi iletişim kurabilen, başarıya teşvik eden, çocukları üzerinde daha az talepleri olan, kuralları uygulamada daha yumuşak davranan ve daha az reddetme eğiliminde olan bireylerdir. Yaş ilerledikçe babaların tutum ve davranışlarındaki bu değişiklikler baba yaşının ergenlerin olumlu sosyal beceri gelişimini arttırdığı yönündeki bulguyu da destekler niteliktedir. Babası ilkokul mezunu olan ergenlerin Olumlu Sosyal Davranışlar alt boyut ve MESSY toplam puan ortalamalarının, lise ve lisans ve lisans üstü mezunu olanların ortalamasına göre daha düşük olduğu saptanmıştır. GüngörmüşÖzkardeş ve Arkonaç (1998) çalışmalarında üniversite eğitimi olan babaların kendilerini sorunlarını paylaşma, yakın olma gibi çocuğu doğrudan etkileyen faaliyetlere işaret eden özellikler ile tanımladıkları görülürken, ilkokul mezunu babaların ise geçimi sağlama gibi çocuğu dolaylı yoldan etkileyen faaliyetler çerçevesinde kendilerini tanımladıklarını saptamışlardır. Eğitim bireylerin tutum ve davranışlarının olumlu yönde değişmesine etki etmektedir. Eğitim seviyesi arttıkça babaların çocuklarına esnek davranma, destek olma vb. babalık becerileri konusunda daha iyi oldukları söylenebilir.

Çalışmada, ergenlerin ebeveyn bağlanma puanları arttıkça olumlu sosyal davranışlarının arttığı ve olumsuz sosyal davranışlarının azaldığı belirlenmiş̧ir. Allen ve arkadaşları (2002) tarafından yapılan ve 2 yıl boyunca devam eden başka bir çalışmada ise 16-18 yaş arasındaki ergenlerin bağlanma güvenliğinin sosyal becerileri arttırdığ 1 , kaygıl1-kararsız bağlanma türünün ise bu dönemde suça yönelik davranışları arttırdığı; kaygılı bağlanmış olan ergenlerin sosyal beceri düzeylerinin önemli ölçüde azaldığı ve suça yönelik davranışlarının arttığı bulunmuştur. Alanyazında yer alan pek çok araştırmada sosyal becerilerle bağlanma arasında anlamlı ilişkiler bulunmuştur (DiTommaso ve ark., 2003; Kumru, Carlo ve Edwards, 2004; Deniz, Hamarta ve Ari, 2005). Araştırmannın bulgusuyla paralel olan bu çalışmalardan da yola çıkılarak bağlanma güvenliğinin sosyal beceri düzeyini etkilediği söylenebilir. 


\section{Sonuç ve Öneriler}

Ergenlerin ebeveyn sosyal beceri düzeyleri ve bağlanma güvenliğinin bazı değişkenlere göre incelendiği çalışma sonucunda; ergenlerin yaşı arttıkça ebeveyn bağlanma güvenliğinin azaldığı, olumsuz davranış sergileme durumlarının arttığı, kızların erkeklere göre daha olumlu sosyal davranışlar sergilediği belirlenmiştir. Çalışmada ebeveynleri ilkokul mezunu olan ergenlerin ebeveynlerine bağlanma güvenliğinin daha düşük olduğu, annesi 31-35 yaş aralığında ve babası 36-40 yaş aralığında ve baba öğrenim durumu lisansüstü olan ergenlerin sosyal beceri düzeylerinin daha iyi olduğu saptanmıştır. Çalışmada, ergenlerin ebeveyn bağlanma puanları arttıkça olumlu sosyal davranışlarının arttığı ve olumsuz sosyal davranışlarının azaldığı belirlenmiştir.

Çalışma sonuçları ve alanyazındaki bilgiler dikkate alındığında, sağlıklı ebeveyn tutumlarının çocuk ve ergenlerin gelişimini doğrudan etkilediği ve tüm yaşamına yansıdığı söylenebilir. Bu nedenle, ilgili sağlı ve eğitim kurumları aracılığıyla anne-babalara çocuk sahibi oldukları andan itibaren çocuk gelişimi ve eğitimi konusunda seminer, konferans gibi eğitim desteği verilebilir. Ergenlik döneminde çocuğu olan ebeveyenlerle, ergenlik dönemine ilişkin bilgi palaşımında bulunulabilir ve ergen yaşta çocuklarıla nitelikli vakit geçirmeye yönelik katkı sağlanabilir. Ergenlerin bağımsız olarak hareket edebilme, sorumluluk üstlenebilme, problemlerinin üstesinden gelebilmeleri için sosyal destek sağlanabilir. Bu amaçla, örgün eğitim kurumlarında görevli eğitimcilerin ergenlik dönemine yönelik bilgilendirmeleri, öğrencileri sosyal paylaşımlarda bulunabilecekleri etkinliklere teşvik etmeleri önerilebilir.

Çalışma 12-14 yaşları arasında sınırlı tutulmuştur. Ergenliğin farklı dönemlerinde özellikle romantik ilişkilerin ortaya çıkmaya başladığı zaman diliminde bağlanma güvenliği ve sosyal beceri düzeyi daha farklı olabilir. Çalışmanın farklı yaşta örneklem gruplarıyla yapılabilir. Verilerin toplanmasında, nitel araştırma yöntemlerinden yararlanılabilir.

\section{Kaynakça}

Allen, J. P., Hauser, S. T. ve Borman-Spurrell, E. (1996). Attachment theory as a framework for understanding sequelae of severe adolescent psychopathology: An 11-year follow-up study. Journal of consulting and clinical psychology, 64(2), 254-263. 
Allen, J. P., Marsh, P., McFarland, C., McElhaney, K. B., Land, D. J., Jodl, K. M. ve Peck, S. (2002). Attachment and autonomy as predictors of the development of social skills and delinquency during midadolescence. Journal of Consulting and Clinical Psychology, 70(1), 56-66.

Armsden, G. C. ve Greenberg, M. T. (1987). The inventory of parent and peer attachment: Individual differences and their relationship to psychological well-being in adolescence. Journal of Youth and Adolescence, 16(5), 427-454.

Bacanlı, H. ve Erdoğan, F. (2003). Matson çocuklarda sosyal becerileri değerlendirme ölçeğinin (MESSY) Türkçe'ye uyarlanması. Kuram ve Uygulamada Eğitim Bilimleri, 3(2), 351-379.

Bayraktar, F., Say1l, M. ve Kumru, A. (2009). Liseli ergenler ve üniversiteli gençlerde benlik saygısı: ebeveyn ve akrana bağlanma, empati ve psikolojik uyum değişkenlerinin rolü. Türk Psikoloji Dergisi, 24(63), 48-63.

Büyüköztürk, Ş., Kılıç-Çakmak, E., Akgün, Ö. E., Karadeniz, Ş. ve Demirel, F. (2013). Bilimsel araştırma yöntemleri. Ankara: Pegem akademi.

Blehar, M. C. (1974). Anxious attachment and defensive reactions associated with day care. Child Development, 45(3), 683-692.

Braddock, B. A., Twyman, K. A., Garrity, M. R., Wang, T., Neary, M. K., Ezzelgot, J. ve Heithaus, J. L. (2015). A few close friends the pediatrician's role in the management of social skills deficits in adolescent children. Clinical Pediatrics, 54(12), 1-8.

Cassidy, J. (1988). Child-mother attachment and the self in six-year-olds. Child Development, 59(1), 121-134.

Christie, D. ve Viner, R. (2005). Adolescent development. British Medical Journal, 330(7486), 301-304.

Çağdaş, A. (2012). Anne-baba-çocuk iletişimi. Ankara: Eğitien Kitap.

Deniz, M., Hamarta, E. ve Ari, R. (2005). An investigation of social skills and loneliness levels of university students with respect to their attachment styles in a sample of Turkish students. Social Behavior and Personality: An International Journal, 33(1), 19-32. 
DiTommaso, E., Brannen-McNulty, C., Ross, L. ve Burgess, M. (2003). Attachment styles, social skills and loneliness in young adults. Personality and Individual Differences, 35(2), 303-312.

Dinç, S. (2014). Baba-bebek arasındaki bağlanma durumu ve etkileyen faktörlerin belirlenmesi. Yayınlanmamış yüksek lisans tezi, İstanbul Üniversitesi Sağl1k Bilimleri Enstitüsü.

Elliott, S., Barnard, J. ve Gresham, F. M. (1989). Preschoolers' social behavior: Teachers' and parents' assessments. Journal of Psychoeducational Assessment, 7(3), 223-234.

Engels, R. C., Finkenauer, C. ve Meeus, W. (2001). Parental attachment and adolescents' emotional adjustment: The associations with social skills and relational competence. Journal of Counseling Psychology, 48(4), 428-439.

Eisenberg, N. ve Morris, S. A. (2004). Moral cognitions and prosocial responding in adolescence. R. M. Lerner ve L. Stinberg, (Ed.), Handbook of adolescent psychology (2. bask1) içinde (155-188). New Jersey: John Wiley\&Sons, Inc, Hoboken.

Güngörmüş-Özkardeş, O. ve Arkonaç, S. (1998). İki farklı eğitim düzeyinde baba olma algısı. M.Ü. Atatürk Eğitim Fakültesi Eğitim Bilimleri Dergisi, 10(10), 253-263.

Jamyang-Tshering, K. (2004). Social competence in preschoolers: An evaluation of the psychometric properties of the preschool social skills rating system (SSRS). Yayınlanmamış doktora tezi, Pace University.

Keler, H. (2008). Liseli ergenlerin transaksiyonel analiz ego durumlart ile bağlanma stilleri arasındaki ilişkinin incelenmesi. Yayınlanmamış yüksek lisans tezi, Marmara Üniversitesi Eğitim Bilimleri Enstitüsü.

Kirchler, E., Palmonari, A. ve Pombeni, M. L. (1993). Developmental tasks and adolescents relationships with their peers and family. S. Jackson ve $\mathrm{H}$. Rodriguez-Tome, (Ed.), Adolescence and its social worlds içinde (147-167). U.K: Lawrence Erlbaum.

Kumru, A. (2002). Prosocial behavior within the family context and its correlates among Turkish early adolescents. Yayınlanmamış doktora tezi, Nebraska University. 
Kumru, A., Carlo, G. ve Edwards, C. P. (2004). Olumlu sosyal davranışların ilişkisel, kültürel, bilişsel ve duyuşsal bazı değişkenlerle ilişkisi. Türk Psikoloji Dergisi, 19(54), 109-125.

Lieberman, M., Doyle, A. B. ve Markiewicz, D. (1999). Developmental patterns in security of attachment to mother and father in late childhood and early adolescence: Associations with peer relations. Child Development, 70(1), 202-213.

Lopez-Turley, N. R. (2003). Are children of young mothers disadvantaged because of their mother's age or family background? Child Development, 74(2), 465-474.

MacDonald, K. (1987). Parent-child physical play with rejected, neglected, and popular boys. Developmental Psychology, 23(5), 705-711.

Matson, J. L., Rotatori, A. F. ve Helsel, W. J. (1983). Development of a rating scale to measure social skills in children: The Matson evaluation of social skills with youngsters (MESSY). Behav Res Theory, 21, 335-340.

Nkwake, A. M. (2009). Mothers' and fathers' perceptions of paternal involvement in child care in Uganda. Childhood in Africa, 1(1), 25-30.

Seven, S. (2006). 6 yaş çocuklarının sosyal beceri düzeyleri ile bağlanma durumları arasındaki ilişkinin incelenmesi. Yayınlanmamış doktora tezi, Gazi Üniversitesi, Eğitim Bilimleri Enstitüsü.

Sümer, N. ve Şendağ, M. A. (2009). Orta çocukluk döneminde ebeveynlere bağlanma, benlik algısı ve kayg1. Türk Psikoloji Dergisi, 24(63), 86-101.

Spear, L. P. (2000). Neurobehavioral changes in adolescence. Current Directions in Psychological Science, 9(4), 111-114.

Tanış, Z. İ. (2014). Yetişkinlerde bağlanma stilleri ve öfke tarzları arasındaki iliş̧kinin incelenmesi. Yayınlanmamış yüksek lisans tezi, Haliç Üniversitesi Sosyal Bilimler Enstitüsü.

Waters, E. ve Cummings, E. M. (2000). A secure base from which to explore close relationships. Child Development, 71(1), 164-172. 